\title{
Rainfall Trend Analysis in Uma Oya Basin, Sri Lanka, and Future Water Scarcity Problems in Perspective of Climate Variability
}

\author{
Bhabishya Khaniya, Isuru Jayanayaka, Pradeep Jayasanka, and Upaka Rathnayake $(D)$ \\ Department of Civil Engineering, Faculty of Engineering, Sri Lanka Institute of Information Technology, Malabe, Sri Lanka \\ Correspondence should be addressed to Upaka Rathnayake; upakasanjeewa@gmail.com
}

Received 22 December 2018; Revised 18 February 2019; Accepted 11 April 2019; Published 8 May 2019

Academic Editor: Marina Baldi

Copyright (C) 2019 Bhabishya Khaniya et al. This is an open access article distributed under the Creative Commons Attribution License, which permits unrestricted use, distribution, and reproduction in any medium, provided the original work is properly cited.

\begin{abstract}
The effect of climate variability on the rainfall pattern is canvassed on the Uma Oya river basin, Sri Lanka, consisting of 5 rainfall gauging stations. The Uma Oya basin $\left(720 \mathrm{~km}^{2}\right)$ is given utmost precedence due to environmental concerns seen in the ongoing Uma Oya multipurpose development project (529 million USD worth) which is expected to divert water to the southeast dry zone of the country while adding $231 \mathrm{GWh}$ /year electricity to the national grid. The rainfall data for a period of 26 years (1992-2017) were analysed using Mann-Kendall's test and Sen's slope estimator test to identify the rainfall trends. Both of these trend analysis test results depict only one negative trend for Hilpankandura Estate for the month of June; however, the seasonal trend analysis and annual trend analysis do not support this observation. Nevertheless, Mann-Kendall's test showed potential positive trends for the 3 rainfall gauging stations Kirklees Estate, Ledgerwatte Estate, and Welimada Group only in the $1^{\text {st }}$ intermediate period (March-April), and this is well supported by the monthly trend analysis. Other than these trends, the results do not show any significant negative trends in the Uma Oya catchment. Therefore, the results vividly explain that there is no threat of water scarcity to the catchment area being resistant to changing global climate for the past 26 years.
\end{abstract}

\section{Introduction}

Climate change and climate variability are not a myth, and many evidences can be found to support them [1-4]. Many researchers believe the human interactions have increased the rate of climate change [5-9]. Climate variability is often referred to as global warming by many people even though it is only one possibility in climate variability [2]. Many researchers try to understand the past, present, and future climate variability through observations [10-12] and theoretical models $[7,13,14]$.

Climate variability involves changes in precipitation and atmospheric temperature, slower winds, and acidification of the ocean. However, atmospheric temperature and precipitation are the two most sensible factors to the people. Between these two, changes in precipitation are one of the most important factors, which impact the society and then determine the overall impact of climate change.
Some researchers predict that the warmer climate enhances the precipitation events [15], however, with more dry intervals and few intensified precipitation (rainfall) events. At the same time, some other researchers argued that the impact of climate change is not measurable on regional rainfalls over the natural variations [16-22]. Nevertheless, some of the cases reveal that there is a strong correlation between the human activities and the climate change [2325]. Studies show that the uneven flood event that occurred in England and Wales in autumn 2000 was due to manmade activities [26-28].

Precipitation in the United Kingdom has changed over the last few decades. It was observed that precipitation has become more intense during the winter months, but less intense during the summer months $[29,30]$. Positive trends were found in wet days using gamma distributions all over the United Kingdom. In addition, nonparametric tests confirmed the increase of precipitation during the winter 
months. Nevertheless, the negative trends in gamma distribution and decreasing trends of precipitation were found in the summer days [29]. The positive precipitation trends in the winter months led to an increase in the flood frequency and the flood magnitude in the United Kingdom [21]. However, the nearby country, Ireland's southwest coast, Valentia shows controversial trends to the precipitation. A 54-year-trend analysis shows clearly an increment of precipitation (10\%), however, during March to October [31, 32]. Months from March to October mark the spring, summer, and autumn months in Ireland. Therefore, this finding by Kiely et al. [32] is interesting as the increment of precipitation is not in the winter months, but in the other months of the year. However, according to McElwain and Sweeney [33], northwestern Ireland follows precipitation trends similar to those of the United Kingdom. Therefore, the spatial variation of precipitation trend analysis would be a more interesting topic to look at to understand the climate variability.

Cannarozzo et al. [34] reported that overall trends in Sicily (Italy) have a negative trend for the entire region by analysing around 250 rain gauges using nonparametric statistical methods. Similar studies for the precipitation (rainfall) trend analysis were carried out over many other regions of the world: Ceballos et al. [35] and De Luis et al. [36] for Spain; Bunting et al. [37] and Hess et al. [38] for African countries; Longobardi and Villani [39] and Philandras et al. [40] for the Mediterranean area; Ahmad et al. [41], Deshmukh and Lunge [42], Kumar et al. [43], and Sridhar and Raviraj [44] for the Indian subcontinent; Gemmer et al. [45] and Zhai et al. [46] for China; Nicholls and Lavery [47] and Salinger and Griffiths [48] for Oceania and de la Casa; and Nasello [49] and Knowles et al. [50] for the American continent.

Rainfall trend analyses were carried out in several important catchments in Sri Lanka. According to Jayawardene et al. [51], average rainfall in Colombo, Sri Lanka, will have a significant annual increase of $3.15 \mathrm{~mm} /$ year, whereas two other cities Kandy and Nuwara Eliya (about 100-200 km away Colombo) will have an annual decrease of 2.88 and $4.87 \mathrm{~mm} /$ year, respectively. Several other researchers including Ampitiyawatta and Guo [52], Herath and Ratnayake [53], Jayawardene et al. [54], Malmgren et al. [55], Ranatunge et al. [56], Suppiah [57], and Wickramagamage [58] have carried out extensive research work to analyse the rainfall trends in many other important areas in Sri Lanka. However, the literature does not show any rainfall trend analysis for the Uma Oya catchment, one of the most important catchments in Sri Lanka.

This paper presents rainfall trend analysis of the Uma Oya catchment using several rainfall stations and their monthly rainfall data. The river flow trends of Uma Oya were then projected using the rainfall trends, thus to identify water scarcity in the catchment, if there are any.

\section{Uma Oya Multipurpose Development Project}

Discussions for the Uma Oya development project were held since 1950s. It was analysed in 1959 with the help of
Americans and Canadians for potential hydropower development. However, in 1968-1969, there was another proposal under the United Nations for the Uma Oya catchment. It was again proposed in 1988-1989 with the help of Germans. In addition, another prefeasibility study was carried out in 1991 by a Sri Lankan construction company not only to develop the hydropower but also to divert some of the excess water to down south of Sri Lanka. The project was never implemented because of various reasons, including the protests by the villagers. However, construction of the project was initiated in 2008 and is about to finish in the coming years (by 2020). It is a multipurpose transbasin project, and therefore, in addition to the hydropower development, it transfers $145 \mathrm{MCM}$ (million cubic meters) to the Kirindi Oya basin in the southeast dry zone for irrigation. It is proposed to develop $231 \mathrm{GWh}$ of hydroelectricity and then add to the national electricity grid. However, there were/are many discussions on the Uma Oya catchment in Sri Lanka due to the Uma Oya multipurpose development project. It has many disadvantages to the ecosystem and the surrounding society, and there were many protests against the development project. However, this ongoing multipurpose development project also has many advantages including renewable hydroelectric power generation and cultivation of thousands of hectares of land. As already stated, on completion, a significant portion of Uma Oya river flow will be transferred to the down south of the country. Therefore, it would be highly interesting to assess the future flow of Uma Oya under the climate variability scenarios to check whether the development project achieves its targets in the future while Uma Oya serving its original tasks (irrigation and hydropower development in the Uma Oya catchment).

\section{Homogeneity Tests for Rainfall Series}

Homogeneity tests express the variability of a data series. This is very important in daily rainfall measurements to confirm whether the data were recorded on the same time daily with the same instrument at the same location [59]. However, this is a tedious task when it comes to recording of daily rainfall measurements in longer time spans (like 30 years or 100 years) as the measuring techniques may have changed over the period, the measuring instruments may have been reinstalled, and so on. Literature gives many methods of identifying the inhomogeneity of data sets. SNHT $[60,61]$, Pettitt's test $[62,63]$, Buishand's test $[64,65]$, and von Neumann's test $[63,66]$ are several homogeneity tests used in the literature.

\section{Mann-Kendall's Test}

Mann [67] proposed a nonparametric test to analyse the trends, and Kendall [68] implemented Mann's test. In addition, Hirsch et al. [69] added the seasonality assessment to the test. The test is now widely known as Mann-Kendall's test for trend analysis. It statistically checks the monotonic upward and downward trends in climate over the time. The test is widely used all over the world $[21,34,36,39,41$, $43,44,70,71]$. 
Mann-Kendall's statistic $S$ is given by the following formula:

$$
S=\sum_{i=1}^{n-1} \sum_{j=i+1}^{n} \operatorname{sgn}\left(x_{j}-x_{i}\right)
$$

where $x_{j}$ and $x_{i}$ are the time series and $n$ is the number of data points in the time series. The sign function "sgn" can be expressed as

$$
\operatorname{sgn}\left(x_{j}-x_{i}\right)= \begin{cases}+1, & >\left(x_{j}-x_{i}\right), \\ 0, & =\left(x_{j}-x_{i}\right), \\ -1, & <\left(x_{j}-x_{i}\right) .\end{cases}
$$

The variance of Mann-Kendall's test is given by the following equation:

$$
\operatorname{Var}(S)=\frac{n(n-1)(2 n+5)-\sum_{i=1}^{m} t_{i}(i)(i-1)(2 i+5)}{18},
$$

where $t_{i}$ is the number of ties up to sample $i$. Then, Mann-Kendall's statistic $Z_{c}$ is given by

$$
Z_{c}= \begin{cases}\frac{S-1}{\sqrt{\operatorname{Var}(S)}}, & S>0, \\ 0, & S=0, \\ \frac{S+1}{\sqrt{\operatorname{Var}(S)}}, & S<0 .\end{cases}
$$

$Z_{c}$ follows the standard normal distribution. A positive $Z_{c}$ value shows an upward trend, whereas negative $Z_{c}$ gives a downward trend for the data period.

\section{Sen's Slope Estimator Test}

The magnitude of the trend at a given time can be found from Sen's slope estimator [72]. The test is widely used in assessing the trend magnitude for rainfall series over the time [41, 43, 70]; Mondal et al., 2012 [44]. Slope for all data pairs can be calculated by

$$
T_{i}=\frac{x_{j}-x_{k}}{j-k} \quad \text { for } i=1,2,3, \ldots, n, j>k,
$$

where $T_{i}$ is the slope and $x_{j}$ and $x_{k}$ are the data values at time $j$ and $k$, respectively. The median of the $n$ values of $T_{i}$ is symbolised as Sen's slope estimator $\left(Q_{i}\right)$ and given by

$$
Q_{i}= \begin{cases}T_{(n+1) / 2}, & n \text { is odd, } \\ \frac{1}{2}\left(T_{n / 2}+T_{(n+2) / 2}\right), & n \text { is even. }\end{cases}
$$

\section{Case Study Application}

As stated above in Introduction, the Uma Oya catchment (has an area of $720 \mathrm{~km}^{2}$ ) is one of the important catchments in Sri Lanka. The catchment has areas from the wet zone and intermediate zone of Sri Lanka. Therefore, it has a rich biodiversity. Uma Oya is one of the major tributaries of Mahaweli River, the longest river in Sri Lanka. Uma Oya starts from Pidurutalagala (Sri Lanka's highest mountain) and reaches Mahaweli River at the Rantambe reservoir. Therefore, it has a significant elevation difference ranging from 2500 meters to 152 meters over the length of the river. The ongoing Uma Oya development program proposed to transfer $145 \mathrm{MCM}$ (million cubic meters) of water annually to the Kirindi Oya basin in the southeast dry zone of the country. However, there are some major critics from the people who live in the catchment for the ongoing development program as the Uma Oya catchment is labelled to an agricultural catchment. Therefore, water is a critical concern for the catchment itself. Nevertheless, a rainfall trend analysis for the catchment is interesting to assess water scarcity in future climate scenarios. Figure 1 shows the Uma Oya basin and the selected rain gauges to analyse in the catchment.

Numerical numbers 1-5 denote the selected rain gauges in the Uma Oya catchment. They are situated in the coordinates of Welimada Group (1) at $6.9044^{\circ}, 80.9044^{\circ}$; Hilpankandura Estate (2) at $6.8757^{\circ}, 809358^{\circ}$; Dyraaba Estate (3) at $6.8865^{\circ}, 80.9419^{\circ}$; Kirklees Estate (4) at $6.9901^{\circ}$, $80.9431^{\circ}$; and Ledgerwatte Estate (5) at $7.0312^{\circ}, 81.0106^{\circ}$. Rainfall data for 26 consecutive years (1992-2017) were obtained from Meteorological Department, Sri Lanka.

Sri Lanka has two major monsoon seasons: northeastern monsoon (from December to February) and southwestern monsoon (from May to September). In addition, it has two intermediate rainfall seasons in between the two monsoons: $1^{\text {st }}$ intermediate season from March to April and $2^{\text {nd }}$ intermediate monsoon from October to November. However, the Uma Oya catchment receives its major rainfall during the northeastern monsoon. In addition, the catchment has average rainfalls during the southwestern monsoon and the $2^{\text {nd }}$ intermediate monsoon. Therefore, the catchment is well known as a green catchment among the residents.

Missing rainfalls due to various reasons (instrument issues and recording issues) were filled by the normal ratio method. Then, the rainfalls were checked for homogeneity using Pettitt's test, SNHT, Buishand's test, and von Neumann's test.

Next, rainfall data were observed to identify simple eyeball trends, before they moved to the statistical models. Annual and monthly rainfall values were used in this mere analysis. However, Mann-Kendall's test and Sen's slope estimator test were applied to the annual, seasonal, and monthly rainfall series in the Uma Oya catchment.

\section{Results and Discussion}

Figure 2 presents the annual rainfall variation in the selected rain gauge stations. The figure clearly shows the spatial and temporal variation of the rainfall. Averagely all of these annual rainfalls show similar patterns with drops and rises. They show an increasing trend to the naked eye. In addition, compared to other years, 2016 had a significant lower rainfall to the catchment. Therefore, it can be considered drought year to the catchment. 


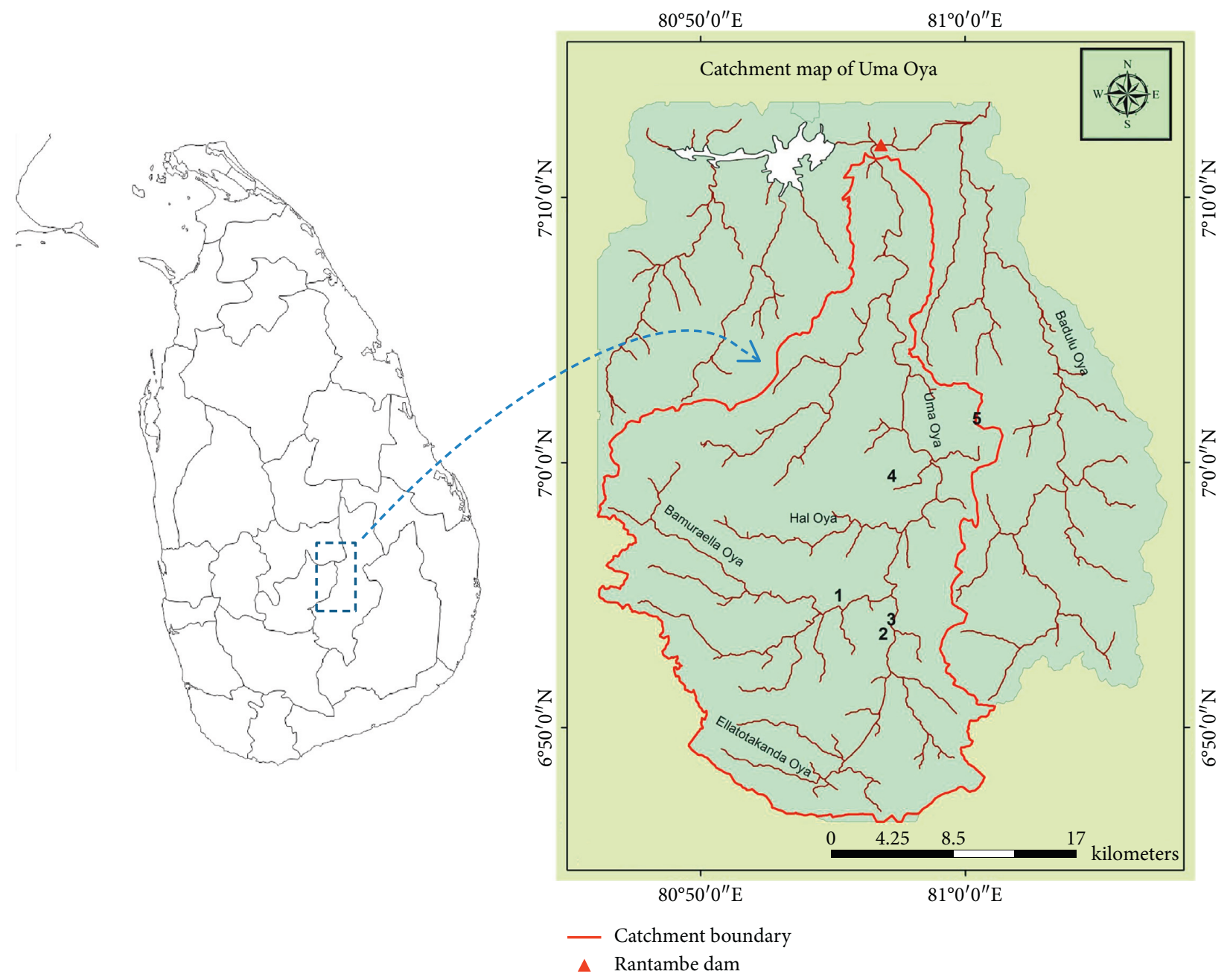

FIgURE 1: Uma Oya catchment and selected rain gauges.

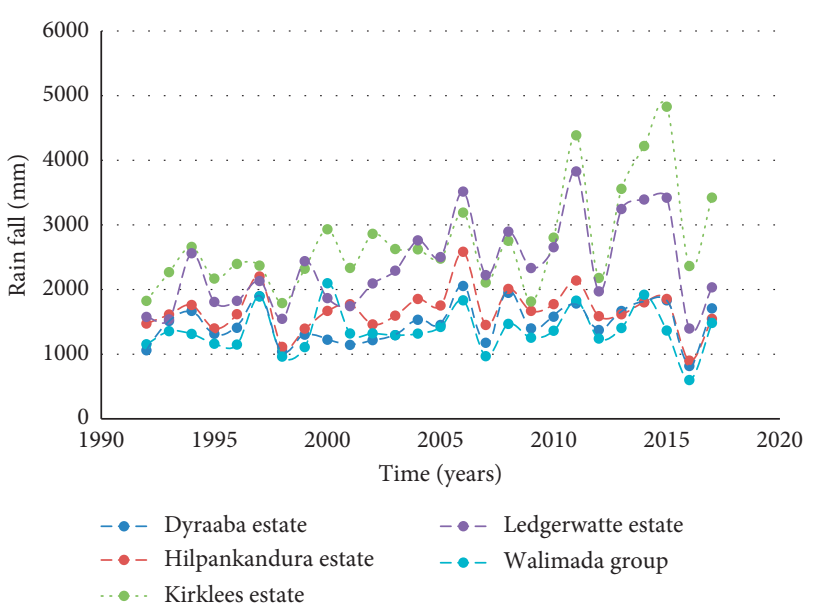

FIgure 2: Annual rainfall distribution.

Tests carried out to check homogeneity of the rainfall data (Pettitt's test, SNHT, and Buishand's test) show that the data series for 5 stations are homogeneous. However, von Neumann's test illustrates a risk of nonhomogeneity in the data series. Table 1 exhibits the results of the trend analysis for annual rainfall data. The table shows there are no significant trends in annual rainfall for Dyraaba Estate, Hilpankandura Estate, and Welimada Group. Interestingly, positive rainfall trends were identified in Kirklees Estate and Ledgerwatte Estate rain gauges. The annual potential rainfall increment to these stations is significant, and the increased rainfall values per year can be seen from Sen's slope values. More importantly, the trend analysis does not identify any potential negative rainfall trend for the Uma Oya catchment. This would be an interesting finding to the people around the area as well as the authorities of the Uma Oya multipurpose development program. The trend analysis suggests that the Uma Oya catchment is not under a serious water scarcity condition.

The analysis was extended to identify the seasonal impact on water resources in the area. The catchment is well famous for agriculture, and more than 30\% of the country's vegetable production comes from the catchment. Therefore, the seasonal rainfall trend analysis would be an interesting topic for the farmers in the area.

Table 2 presents the statistics from Mann-Kendall's test and Sen's slope estimator test for the seasonal rainfalls. It can be seen herein that only three rain gauge stations show potential trends for rainfall. They are Kirklees Estate, Ledgerwatte Estate, and Welimada Group. Even though 
TABLE 1: Results of trend analysis for annual rainfall.

\begin{tabular}{lcc}
\hline Rain gauge station & Significant (S)/insignificant (IS) & Sen's slope $Q_{i}(\mathrm{~mm} / \mathrm{year})$ \\
\hline Dyraaba Estate & IS & NA \\
Hilpankandura Estate & IS & NA \\
Kirklees Estate & $\mathrm{S}$ & 48.0 \\
Ledgerwatte Estate & $\mathrm{S}$ & 59.3 \\
Welimada Group & IS & NA \\
\hline
\end{tabular}

TABle 2: Results of Mann-Kendall's test and Sen's slope estimator test for seasons.

\begin{tabular}{|c|c|c|c|}
\hline Rain gauge station & Rainfall season & Significant (S)/insignificant (IS) & Sen's slope $Q_{i}(\mathrm{~mm} /$ season in year $)$ \\
\hline \multirow{4}{*}{ Dyraaba Estate } & $1^{\text {st }}$ & IS & NA \\
\hline & SW & IS & NA \\
\hline & $2^{\text {nd }}$ & IS & NA \\
\hline & NE & IS & NA \\
\hline \multirow{4}{*}{ Hilpankandura Estate } & $1^{\text {st }}$ & IS & NA \\
\hline & SW & IS & NA \\
\hline & $2^{\text {nd }}$ & IS & NA \\
\hline & $\mathrm{NE}$ & IS & NA \\
\hline \multirow{4}{*}{ Kirklees Estate } & $1^{\text {st }}$ & $\mathrm{S}$ & 16.1 \\
\hline & SW & IS & NA \\
\hline & $2^{\text {nd }}$ & IS & NA \\
\hline & $\mathrm{NE}$ & IS & NA \\
\hline \multirow{4}{*}{ Ledgerwatte Estate } & $1^{\text {st }}$ & S & 13.6 \\
\hline & SW & IS & NA \\
\hline & $2^{\text {nd }}$ & IS & NA \\
\hline & $\mathrm{NE}$ & IS & NA \\
\hline \multirow{4}{*}{ Welimada Group } & $1^{\text {st }}$ & $S$ & 5.5 \\
\hline & SW & IS & \\
\hline & $2^{\text {nd }}$ & IS & \\
\hline & $\mathrm{NE}$ & IS & \\
\hline
\end{tabular}

$1^{\text {st }}: 1^{\text {st }}$ intermediate season; SW: southwestern monsoon; $2^{\text {nd }}: 2^{\text {nd }}$ intermediate season; NE: northeastern monsoon.

Dyraaba Estate and Hilpankandura Estate are closer in distance to Welimada Group, they do not show a potential rainfall trend. This is interesting, and it would be interesting to observe the topography of the surrounding area. Nevertheless, the Welimada area in Sri Lanka is a plateau that may have caused the spatial variation of the rainfalls.

It is interesting to observe the trend results. A positive rainfall trend can be found in Kirklees Estate, Ledgerwatte Estate, and Welimada Group; however, the trends are only visible in the $1^{\text {st }}$ intermediate period (March-April). The results show a reasonable concurrence to the annual rainfall trend analysis. However, the Welimada Group rain gauge shows a positive trend in the seasonal rainfall analysis which was not shown in the annual rainfall trend analysis. Nevertheless, the increased amount of rainfall for the Welimada Group is around $5.5 \mathrm{~mm}$ per the $1^{\text {st }}$ intermediate season.

It is interesting to have positive rainfall trends in the $1^{\text {st }}$ intermediate season as the Uma Oya catchment has its lowest rainfall during this season. Therefore, the farmers around the catchment would be in favor of the positive trend. The trend increased the rainfall significantly for Kirklees Estate and Ledgerwatte Estate $(16.1 \mathrm{~mm}$ and $13.6 \mathrm{~mm}$ per season) and, however, as stated above, averagely for Welimada Group (5.5 mm per season).

Importantly, the trend analysis results do not show any negative trends for any season. Therefore, it can be justified that water availability in the catchment was not affected over the 26 years. This observation leads to further comment on the future water availability in the Uma Oya catchment. Therefore, it can be projected that there is no critical crisis for water availability in the Uma Oya catchment.

However, the trend analysis discussion was taken up to the monthly intervals. Figures 3(a) and 3(b) show the temporal variation of rainfall for years 2011 and 2016, respectively.

Year 2016 was identified as a slightly drought year, and Figure 3(b) clearly shows the reduction of rainfall. The range of the rainfall axis reduced to half of that in year 2011. However, this reduction happened during the early months of the year. However, the variations show a similar pattern. Figures 4(a)-4(e) show the rainfall variation in several years for the five rain gauge stations. Eyeball trends were identified in Figures 4(a)-4(e). However, it is complex to visualise such a trend; instead rainfall peak migration can be seen with time.

Table 3 presents the trend analysis results on monthly basis for the five rain gauge stations. Kirklees Estate, Ledgerwatte Estate, and Welimada Group show positive rainfall trends in March. This observation coincides with the seasonal rainfall trends as March is in the $1^{\text {st }}$ intermediate season of the year. Therefore, the positive trend in these three gauging stations is further accepted from the 


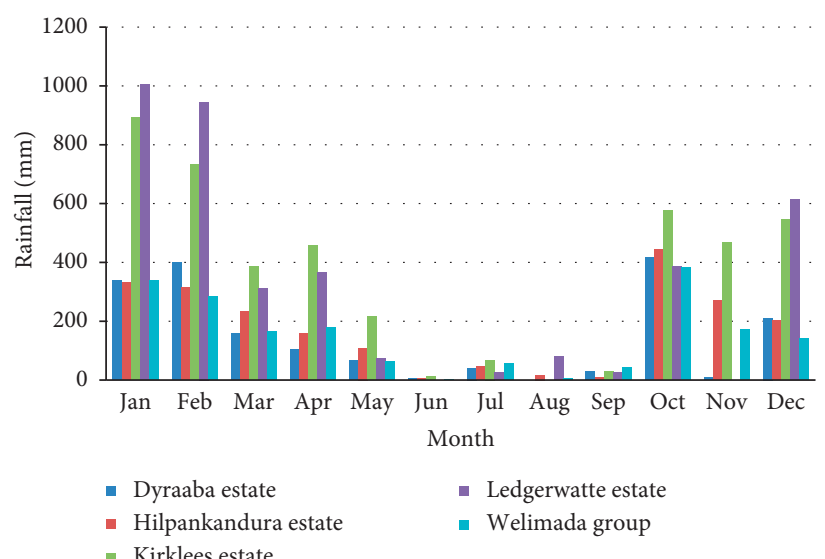

(a)

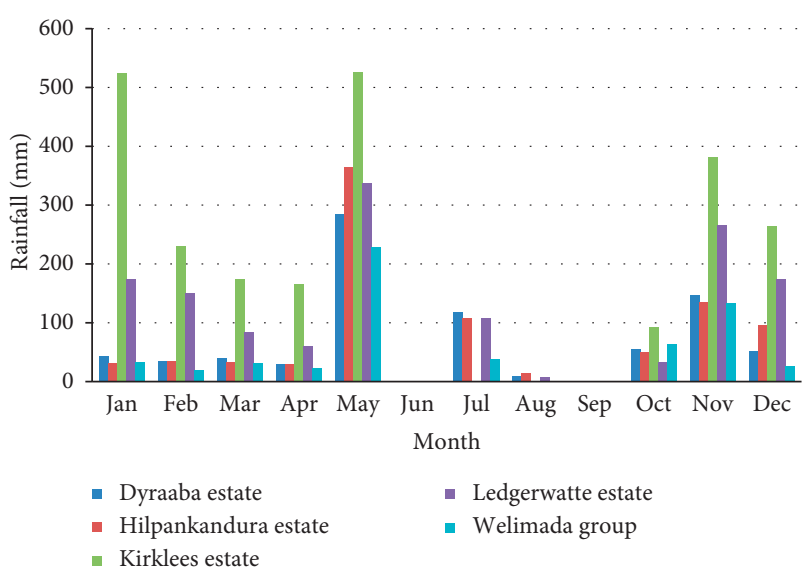

(b)

FIgURE 3: Monthly rainfall variation for years (a) 2011 and (b) 2016.

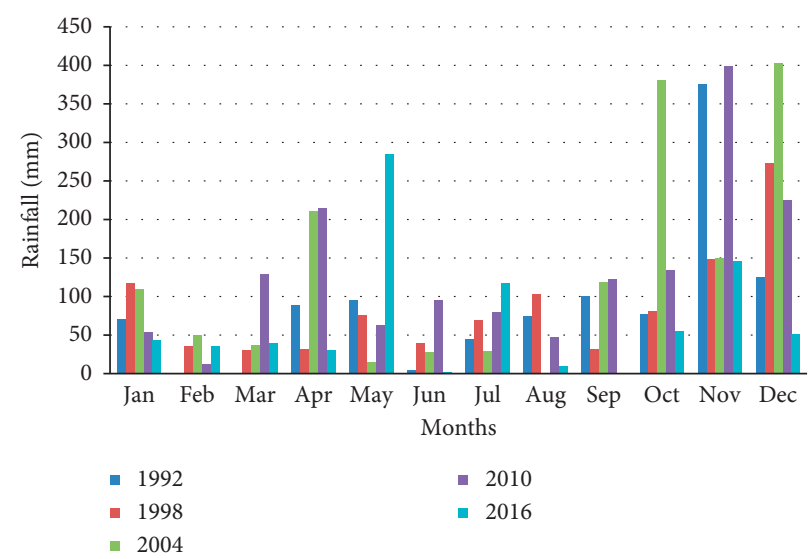

(a)

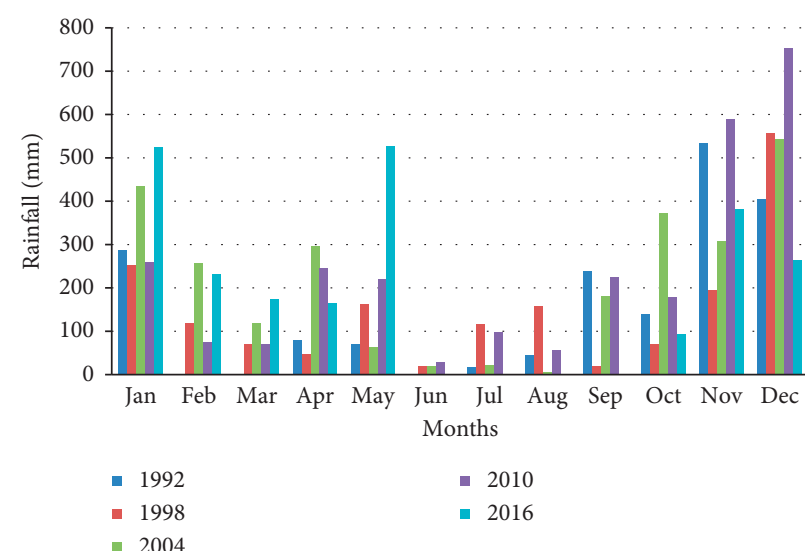

(c)

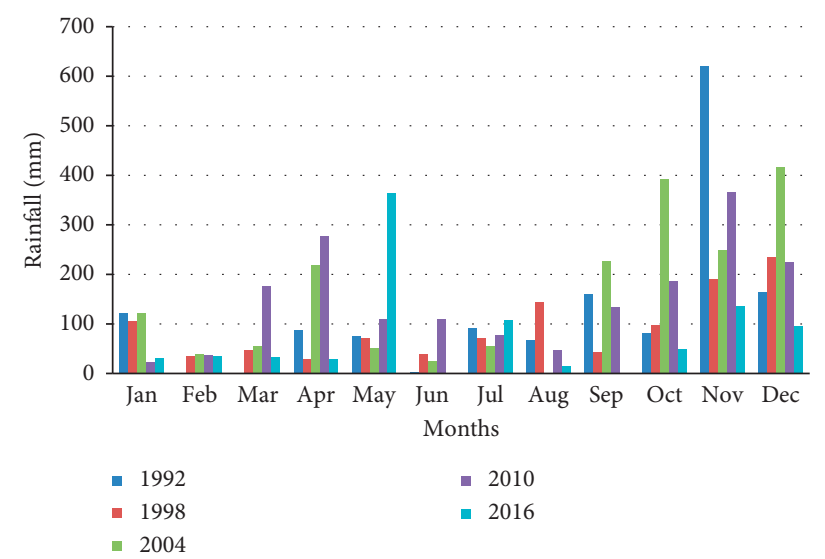

(b)

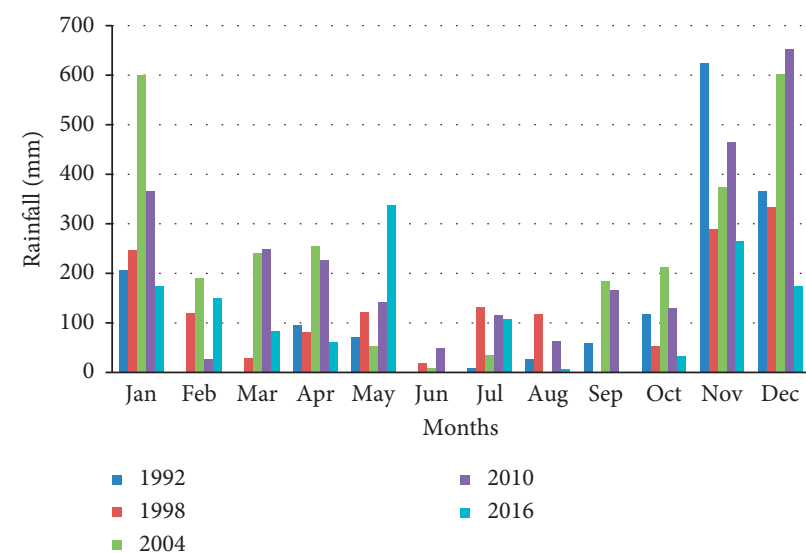

(d)

Figure 4: Continued. 


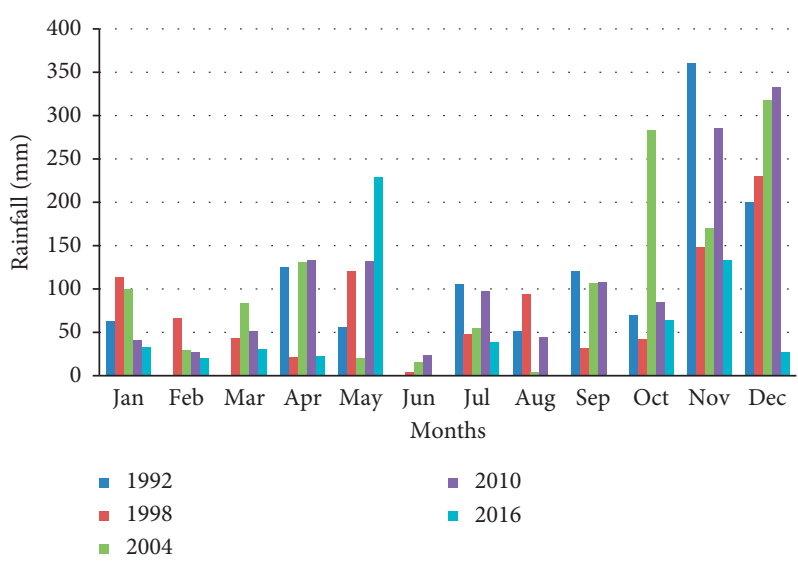

(e)

FIGURE 4: Rainfall variation for five rain gauges: (a) Dyraaba Estate. (b) Hilpankandura Estate. (c) Kirklees Estate. (d) Ledgerwatte Estate. (e) Welimada Group.

TABLE 3: Trend analysis results on monthly basis.

\begin{tabular}{|c|c|c|c|c|c|}
\hline \multirow{2}{*}{ Month } & \multicolumn{5}{|c|}{ Sen's slope $(\mathrm{mm} / \mathrm{month}$ in year) } \\
\hline & Dyraaba Estate & Hilpankandura Estate & Kirklees Estate & Ledgerwatte Estate & Welimada Group \\
\hline Jan & IS & IS & IS & IS & IS \\
\hline Feb & IS & IS & IS & IS & IS \\
\hline Mar & IS & IS & 7.2 & 4.3 & 3.2 \\
\hline Apr & IS & IS & IS & IS & IS \\
\hline May & IS & IS & IS & IS & IS \\
\hline Jun & IS & -2.7 & IS & IS & IS \\
\hline Jul & IS & IS & IS & IS & IS \\
\hline Aug & IS & IS & IS & IS & IS \\
\hline Sep & IS & IS & IS & IS & IS \\
\hline Oct & IS & IS & IS & IS & IS \\
\hline Nov & IS & IS & IS & IS & IS \\
\hline Dec & IS & IS & IS & IS & IS \\
\hline
\end{tabular}

IS: insignificant.

monthly trend analysis. However, a negative trend was found in the month of June for the Hilpankandura Estate. This is interesting as it was not found in the annual and seasonal rainfall trend analysis. However, it is recommended to further analyse the trends using more monthly rainfall data.

As already stated, the ongoing Uma Oya development program proposed to transfer $145 \mathrm{MCM}$ of water annually from Uma Oya to Kirindi Oya. This transfer was proposed due to excess of water in the Uma Oya basin. This can be justified by regular spills from the Rantambe dam. However, the Uma Oya water is directly responsible for hydropower generation in the Rantambe reservoir in Mahaweli Development Project in Sri Lanka. Therefore, it would be interesting to observe water availability in the Rantambe reservoir after completion of the Uma Oya development project.

However, with the aid of the above results of trend analysis, it can be concluded herein that the Uma Oya catchment would not be facing any recent future water scarcity due to climate variability. In fact, the analysis shows an increment of rainfall in Kirklees Estate, Ledgerwatte Estate, and Welimada Group. More importantly, it was found that these increments are in the $1^{\text {st }}$ intermediate season of the year. As stated above, the Uma Oya catchment gets its majority of rain during the northeastern monsoon; however, it has some significant rainfall during the southwestern monsoon and $2^{\text {nd }}$ intermediate season. Therefore, the results from the trend analysis are highly interesting. The Uma Oya catchment gets an increased rainfall in the $1^{\text {st }}$ intermediate season, and therefore, increased runoff can be predicted from the received increased rainfalls in the $1^{\text {st }}$ intermediate season. The monthly results revealed that this increment would be in March of the year, and therefore, planners can start their agricultural and other water-related activities accordingly.

Therefore, more spills in Rantambe can be expected in the future. This is not only due to the increased runoff in Uma Oya but also due to the reduction of capacity of the Rantambe reservoir owing to the ongoing siltation/ sedimentation issue. Therefore, if done carefully, the transfer of 145 MCM of water from Uma Oya to Kirindi Oya would not be a greater issue. However, this is only in the volumetric perspective of river flows. It may be a potential solution to the frequent spills in the Rantambe reservoir too.

Therefore, it is necessary to carry out in-depth analysis to understand other issues related to transfer of water from 
Uma Oya to Kirindi Oya. This should include a detailed analysis of social and economic activities of the people who live in the Uma Oya catchment.

\section{Conclusions}

Rainfall data for five rain gauges in one of the most important catchments in Sri Lanka were tested for the rainfall trends. The analysis emphasises the importance of the selected catchment due to the ongoing Uma Oya development program. The results show that there are no significant negative rainfall trends in the catchment over the last 26 years. Positive rainfall trends can be seen in three rain gauges (Kirklees Estate, Ledgerwatte Estate, and Welimada Group) during the $1^{\text {st }}$ intermediate season, and they were further justified by the monthly trend analysis. Therefore, it can be assumed that the runoff of the Uma Oya catchment is in the increasing phase during the $1^{\text {st }}$ intermediate season and concluded that there is no severe water crisis in the catchment due to the ongoing climate change in the Uma Oya catchment. In addition, the increased runoff due to the positive trends would be worth to transfer to Kirindi Oya using the ongoing Uma Oya multipurpose development project. However, it is recommended to conduct a detailed analysis using more rainfall data and also to conduct a downscaling analysis of the future rainfall variations in the catchment.

\section{Data Availability}

The rainfall data and the analysis data are available from the corresponding author upon request.

\section{Disclosure}

The research was carried out in the Sri Lanka Institute of Information Technology environment.

\section{Conflicts of Interest}

The authors declare that there are no conflicts of interest. The first three authors are bachelor's students of the Civil Engineering Degree Program, while the corresponding author is a senior lecturer in the Faculty of Engineering, Sri Lanka Institute of Information Technology, Sri Lanka.

\section{References}

[1] W. N. Adger, S. Huq, K. Brown, D. Conway, and M. Hulme, "Adaptation to climate change in the developing world," Progress in Development Studies, vol. 3, no. 3, pp. 179-195, 2003.

[2] J. P. Schuldt, S. H. Konrath, and N. Schwarz, "“'Global warming" or "climate change"?: Whether the planet is warming depends on question wording," Public Opinion Quarterly, vol. 75, no. 1, pp. 115-124, 2011.

[3] A. Spence, W. Poortinga, and N. Pidgeon, "The psychological distance of climate change," Risk Analysis, vol. 32, no. 6, pp. 957-972, 2011.
[4] E. U. Weber and P. C. Stern, "Public understanding of climate change in the United States," American Psychologist, vol. 66, no. 4, pp. 315-328, 2011.

[5] F. S. Chapin, E. S. Zavaleta, V. T. Eviner et al., "Consequences of changing biodiversity," Nature, vol. 405, no. 6783, pp. 234-242, 2000.

[6] O. Hoegh-Guldberg and J. F. Bruno, "The impact of climate change on the world's marine ecosystems," Science, vol. 328, no. 5985, pp. 1523-1528, 2010.

[7] T. R. Karl, "Modern global climate change," Science, vol. 302, no. 5651, pp. 1719-1723, 2003.

[8] R. G. Pearson and T. P. Dawson, "Predicting the impacts of climate change on the distribution of species: are bioclimate envelope models useful?," Global Ecology and Biogeography, vol. 12, no. 5, pp. 361-371, 2003.

[9] G.-R. Walther, E. Post, P. Convey et al., "Ecological responses to recent climate change," Nature, vol. 416, no. 6879, pp. 389-395, 2002.

[10] D. R. Easterling, G. Meehl, C. Parmesan, S. Changnon, T. Karl, and L. Mearns, "Climate extremes: observations, modeling, and impacts," Science, vol. 289, no. 5487, pp. 2068-2074, 2000.

[11] R. Knutti, T. F. Stocker, F. Joos, and G.-K. Plattner, "Constraints on radiative forcing and future climate change from observations and climate model ensembles," Nature, vol. 416, no. 6882, pp. 719-723, 2002.

[12] A. Soja, N. Tchebakova, N. French et al., "Climate-induced boreal forest change: predictions versus current observations," Global and Planetary Change, vol. 56, no. 3-4, pp. 274-296, 2007.

[13] Y. J. Kim, S. D. Eckermann, and H. Y. Chun, “An overview of the past, present and future of gravity-wave drag parametrization for numerical climate and weather prediction models," Atmosphere-Ocean, vol. 41, no. 1, pp. 65-98, 2003.

[14] C. Tebaldi and R. Knutti, "The use of the multi-model ensemble in probabilistic climate projections," Philosophical Transactions of the Royal Society A: Mathematical, Physical and Engineering Sciences, vol. 365, no. 1857, pp. 2053-2075, 2007.

[15] O. Christensen and J. Christensen, "Intensification of extreme European summer precipitation in a warmer climate," Global and Planetary Change, vol. 44, no. 1-4, pp. 107-117, 2004.

[16] R. Chandler, "Irish floods, changing climate and generalised linear models," Newsletter of British Hydrological Society, vol. 69, pp. 5-7, 2001.

[17] L. Guowei and W. Jingpeng, "A study of extreme floods in China for the past 100years," in Proceedings of the IUGG, Hydrological Extremes: Understanding, Predicting, Mitigating, pp. 109-119, IHS Publications, Birmingham, UK, July 1999.

[18] Z. Kundzewicz and A. Robson, "Detecting trend and other changes in hydrological data. world climate programme data and monitoring, WCDMP-45," WMO/TD Report no. 1013, World Meteorological Organization, Geneva, Switzerland, 2000.

[19] G. Lindstrom, "Trends and variability in Swedish floods," in Proceedings of the IUGG, Hydrological Extremes: Understanding, Predicting, Mitigating, pp. 91-98, IHS Publications, Birmingham, UK, July 1999.

[20] H. F. Lins and J. R. Slack, "Streamflow trends in the United States," Geophysical Research Letters, vol. 26, no. 2, pp. 227230, 1999.

[21] A. J. Robson, "Evidence for trends in UK flooding," Philosophical Transactions of the Royal Society of London. Series A: Mathematical, Physical and Engineering Sciences, vol. 360, no. 1796, pp. 1327-1343, 2002. 
[22] A. J. Robson, T. K. Jones, D. W. Reed, and A. C. Bayliss, "A study of national trend and variation in UK floods," International Journal of Climatology, vol. 18, no. 2, pp. 165-182, 1998.

[23] M. Du, S. Kawashima, S. Yonemura, X. Zhang, and S. Chen, "Mutual influence between human activities and climate change in the Tibetan Plateau during recent years," Global and Planetary Change, vol. 41, no. 3-4, pp. 241-249, 2004.

[24] N. Oreskes, "The scientific consensus on climate change," Science, vol. 306, no. 5702, p. 1686, 2004.

[25] H. Wang, Z. Yang, Y. Saito, J. Liu, X. Sun, and Y. Wang, "Stepwise decreases of the Huanghe (Yellow River) sediment load (1950-2005): impacts of climate change and human activities," Global and Planetary Change, vol. 57, no. 3-4, pp. 331-354, 2007.

[26] A. Kay, R. Jones, and N. Reynard, "RCM rainfall for UK flood frequency estimation. II. Climate change results," Journal of Hydrology, vol. 318, no. 1-4, pp. 163-172, 2006.

[27] I. Lorenzoni, S. Nicholson-Cole, and L. Whitmarsh, "Barriers perceived to engaging with climate change among the UK public and their policy implications," Global Environmental Change, vol. 17, no. 3-4, pp. 445-459, 2007.

[28] C. Prudhomme, D. Jakob, and C. Svensson, "Uncertainty and climate change impact on the flood regime of small UK catchments," Journal of Hydrology, vol. 277, no. 1-2, pp. 1-23, 2003.

[29] T. J. Osborn and M. Hulme, "Evidence for trends in heavy rainfall events over the UK," Philosophical Transactions of the Royal Society of London. Series A: Mathematical, Physical and Engineering Sciences, vol. 360, no. 1796, pp. 1313-1325, 2002.

[30] T. J. Osborn, M. Hulme, P. D. Jones, and T. A. Basnett, "Observed trends in the daily intensity of United Kingdom precipitation," International Journal of Climatology, vol. 20, no. 4, pp. 347-364, 2000.

[31] G. Kiely, "Climate change in Ireland from precipitation and streamflow observations," Advances in Water Resources, vol. 23, no. 2, pp. 141-151, 1999.

[32] G. Kiely, J. Albertson, and M. Parlange, "Recent trends in diurnal variation of precipitation at Valentia on the west coast of Ireland," Journal of Hydrology, vol. 207, no. 3-4, pp. 270279, 1998.

[33] L. McElwain and J. Sweeney, "Climate change in Irelandrecent trends in temperature and precipitation," Irish Geography, vol. 36, no. 2, pp. 97-111, 2003.

[34] M. Cannarozzo, L. V. Noto, and F. Viola, "Spatial distribution of rainfall trends in Sicily (1921-2000)," Physics and Chemistry of the Earth, Parts A/B/C, vol. 31, no. 18, pp. 1201-1211, 2006.

[35] A. Ceballos, J. Martínez-Fernández, and M. Á. LuengoUgidos, "Analysis of rainfall trends and dry periods on a pluviometric gradient representative of Mediterranean climate in the Duero Basin, Spain," Journal of Arid Environments, vol. 58, no. 2, pp. 215-233, 2004.

[36] M. De Luis, J. Raventos, J. Gonzalez-Hidalgo, J. Sanchez, and J. Cortina, "Spatial analysis of rainfall trends in the region of Valencia (East Spain)," International Journal of Climatology, vol. 20, no. 12, pp. 1451-1469, 2000.

[37] A. Bunting, M. Dennett, J. Elston, and J. Milford, "Rainfall trends in the West African Sahel," Quarterly Journal of the Royal Meteorological Society, vol. 102, no. 431, pp. 59-64, 1976.

[38] T. Hess, W. Stephens, and U. Maryah, "Rainfall trends in the north east arid zone of Nigeria 1961-1990," Agricultural and Forest Meteorology, vol. 74, no. 1-2, pp. 87-97, 1995.
[39] A. Longobardi and P. Villani, "Trend analysis of annual and seasonal rainfall time series in the Mediterranean area," International Journal of Climatology, vol. 30, no. 10, pp. 15381546, 2009.

[40] C. M. Philandras, P. T. Nastos, J. Kapsomenakis, K. C. Douvis, G. Tselioudis, and C. S. Zerefos, "Long term precipitation trends and variability within the Mediterranean region," Natural Hazards and Earth System Sciences, vol. 11, no. 12, pp. 3235-3250, 2011.

[41] I. Ahmad, D. Tang, T. Wang, M. Wang, and B. Wagan, "Precipitation trends over time using Mann-Kendall and spearman's rho tests in Swat River Basin, Pakistan," Advances in Meteorology, vol. 2015, Article ID 431860, 15 pages, 2015.

[42] D. T. Deshmukh and H. S. Lunge, "Trend assessment in climatic variables by Mann Kendall and $t$-test: a case study of Yavatmal district in Vidarbha, India," International Journal of Scientific Research, vol. 2, no. 5, pp. 597-600, 2012.

[43] V. Kumar, S. K. Jain, and Y. Singh, "Analysis of long-term rainfall trends in India," Hydrological Sciences Journal, vol. 55, no. 4, pp. 484-496, 2010.

[44] S. I. Sridhar and A. Raviraj, "Statistical trend analysis of rainfall in Amaravathi river basin using Mann-Kendall test," Current World Environment, vol. 12, no. 1, pp. 89-96, 2017.

[45] M. Gemmer, S. Becker, and T. Jiang, "Observed monthly precipitation trends in China 1951-2002," Theoretical and Applied Climatology, vol. 77, no. 1-2, pp. 39-45, 2004.

[46] P. Zhai, X. Zhang, H. Wan, and X. Pan, "Trends in total precipitation and frequency of daily precipitation extremes over China," Journal of Climate, vol. 18, no. 7, pp. 1096-1108, 2005.

[47] N. Nicholls and B. Lavery, "Australian rainfall trends during the twentieth century," International Journal of Climatology, vol. 12, no. 2, pp. 153-163, 1992.

[48] M. J. Salinger and G. M. Griffiths, "Trends in New Zealand daily temperature and rainfall extremes," International Journal of Climatology, vol. 21, no. 12, pp. 1437-1452, 2001.

[49] A. De la Casa and O. Nasello, "Breakpoints in annual rainfall trends in Córdoba, Argentina," Atmospheric Research, vol. 95, no. 4, pp. 419-427, 2010.

[50] N. Knowles, M. D. Dettinger, and D. R. Cayan, "Trends in snowfall versus rainfall in the Western United States," Journal of Climate, vol. 19, no. 18, pp. 4545-4559, 2006.

[51] H. Jayawardene, D. Sonnadara, and D. Jayewardene, "Trends of rainfall in Sri Lanka over the last century," Sri Lankan Journal of Physics, vol. 6, pp. 7-17, 2005.

[52] A. Ampitiyawatta and S. Guo, "Precipitation trends in the Kalu Ganga basin in Sri Lanka," Journal of Agricultural Sciences, vol. 4, no. 1, pp. 10-18, 2010.

[53] S. Herath and U. Ratnayake, "Monitoring rainfall trends to predict adverse impacts-a case study from Sri Lanka (19641993)," Global Environmental Change, vol. 14, pp. 71-79, 2004.

[54] H. Jayawardene, D. Jayewardene, and D. Sonnadara, "Interannual variability of precipitation in Sri Lanka," Journal of the National Science Foundation of Sri Lanka, vol. 43, no. 1, pp. 75-82, 2015.

[55] B. A. Malmgren, R. Hulugalla, Y. Hayashi, and T. Mikami, "Precipitation trends in Sri Lanka since the 1870s and relationships to El Niño-Southern oscillation," International Journal of Climatology, vol. 23, no. 10, pp. 1235-1252, 2003.

[56] E. Ranatunge, B. Malmgren, Y. Hayashi et al., "Changes in the southwest monsoon mean daily rainfall intensity in Sri Lanka: relationship to the El Niño-Southern Oscillation," Paleogeography, Paleoclimatology, Paleoecology, vol. 197, no. 1-2, pp. 1-14, 2003. 
[57] R. Suppiah, "Extremes of the southern oscillation phenomenon and the rainfall of Sri Lanka," International Journal of Climatology, vol. 17, no. 1, pp. 87-101, 1997.

[58] P. Wickramagamage, "Spatial and temporal variation of rainfall trends of Sri Lanka," Theoretical and Applied Climatology, vol. 125, no. 3-4, pp. 427-438, 2015.

[59] H. M. Kang and F. Yusof, "Homogeneity tests on daily rainfall series in Peninsular Malaysia," International Journal of Contemporary Mathematical Sciences, vol. 7, no. 1, pp. 9-22, 2012.

[60] H. Alexandersson and A. Moberg, "Homogenization of Swedish temperature data. Part I: homogeneity test for linear trends," International Journal of Climatology, vol. 17, no. 1, pp. 25-34, 1997.

[61] M. N. Khaliq and T. B. M. J. Ouarda, "On the critical values of the standard normal homogeneity test (SNHT)," International Journal of Climatology, vol. 27, no. 5, pp. 681-687, 2007.

[62] S. Sahin and H. K. Cigizoglu, "Homogeneity analysis of Turkish meteorological data set," Hydrological Processes, vol. 24, no. 8, pp. 981-992, 2010.

[63] J. B. Wijngaard, A. M. G. Klein Tank, and G. P. Können, "Homogeneity of 20th century European daily temperature and precipitation series," International Journal of Climatology, vol. 23, no. 6, pp. 679-692, 2003.

[64] H. Alexandersson, "A homogeneity test applied to precipitation data," Journal of Climatology, vol. 6, no. 6, pp. 661-675, 1986.

[65] T. Buishand, "Some methods for testing the homogeneity of rainfall records," Journal of Hydrology, vol. 58, no. 1-2, pp. 11-27, 1982.

[66] N. Hofstra, M. Haylock, M. New, and P. Jones, "Testing E-OBS European high-resolution gridded data set of daily precipitation and surface temperature," Journal of Geophysical Research, vol. 114, no. 21, pp. 1-16, 2009.

[67] H. B. Mann, "Nonparametric tests against trend," Econometrica, vol. 13, no. 3, pp. 245-259, 1945.

[68] M. Kendall, Rank Correlation Methods, Charles Griffin \& Co. Ltd., London, UK, 4th edition, 1975.

[69] R. M. Hirsch, J. R. Slack, and R. A. Smith, "Techniques of trend analysis for monthly water quality data," Water Resources Research, vol. 18, no. 1, pp. 107-121, 1982.

[70] B. Khaniya, H. G. Priyantha, N. Baduge, H. M. Azamathulla, and U. Rathnayake, "Impact of climate variability on hydropower generation: a case study from Sri Lanka," ISH Journal of Hydraulic Engineering, pp. 1-9, 2018.

[71] A. Mondal, S. Kundu, and A. Mukhopadhyay, "Rainfall trend analysis by Mann-Kendall test: a case study of north-eastern part of Cuttack district, Orissa," International Journal of Geology, Earth and Environmental Sciences, vol. 2, no. 1, pp. 70-78, 2012.

[72] P. K. Sen, "Estimates of the regression coefficient based on Kendall's Tau," Journal of the American Statistical Association, vol. 63, no. 324, pp. 1379-1389, 1968. 

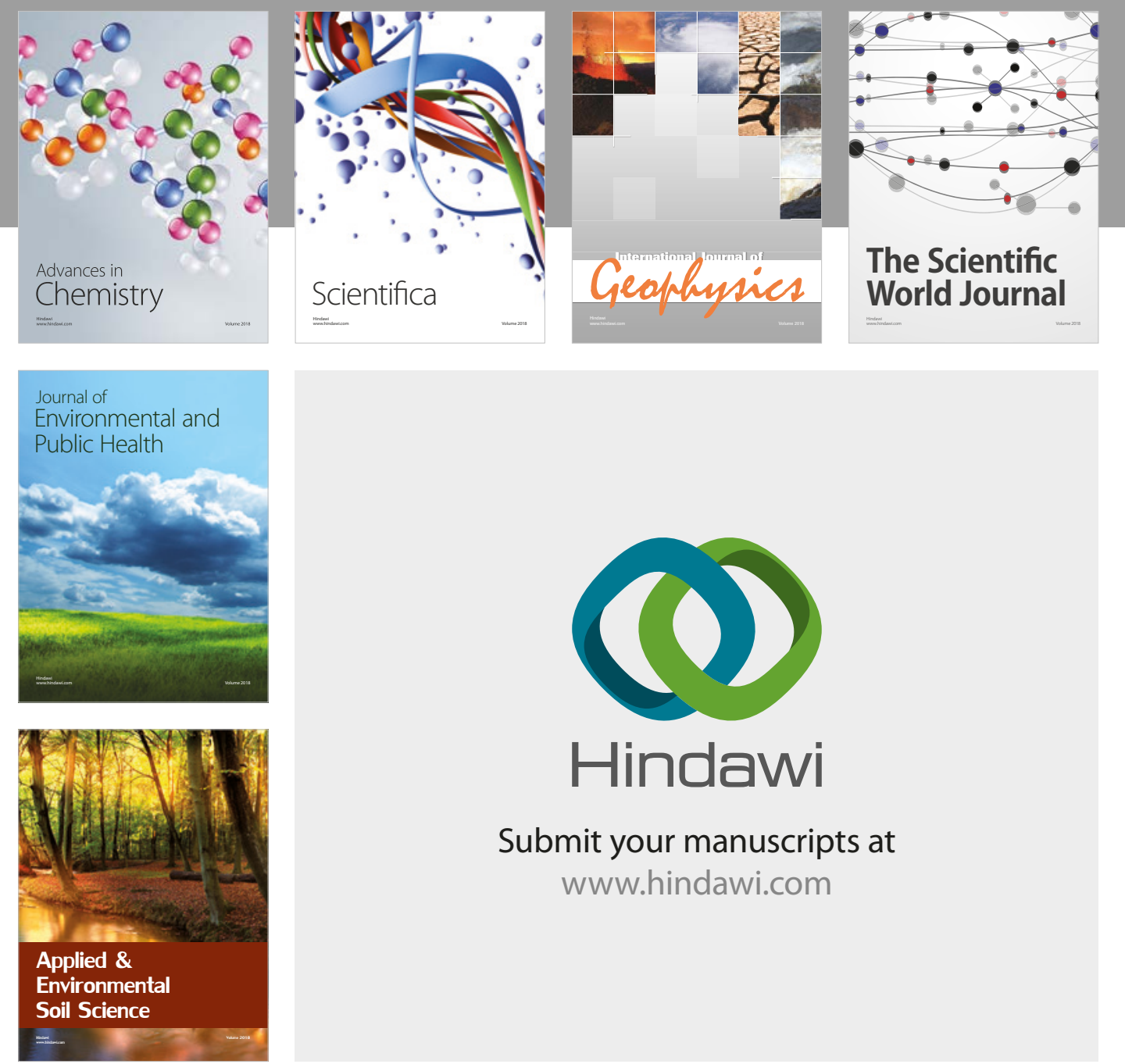

The Scientific

\section{World Journal}
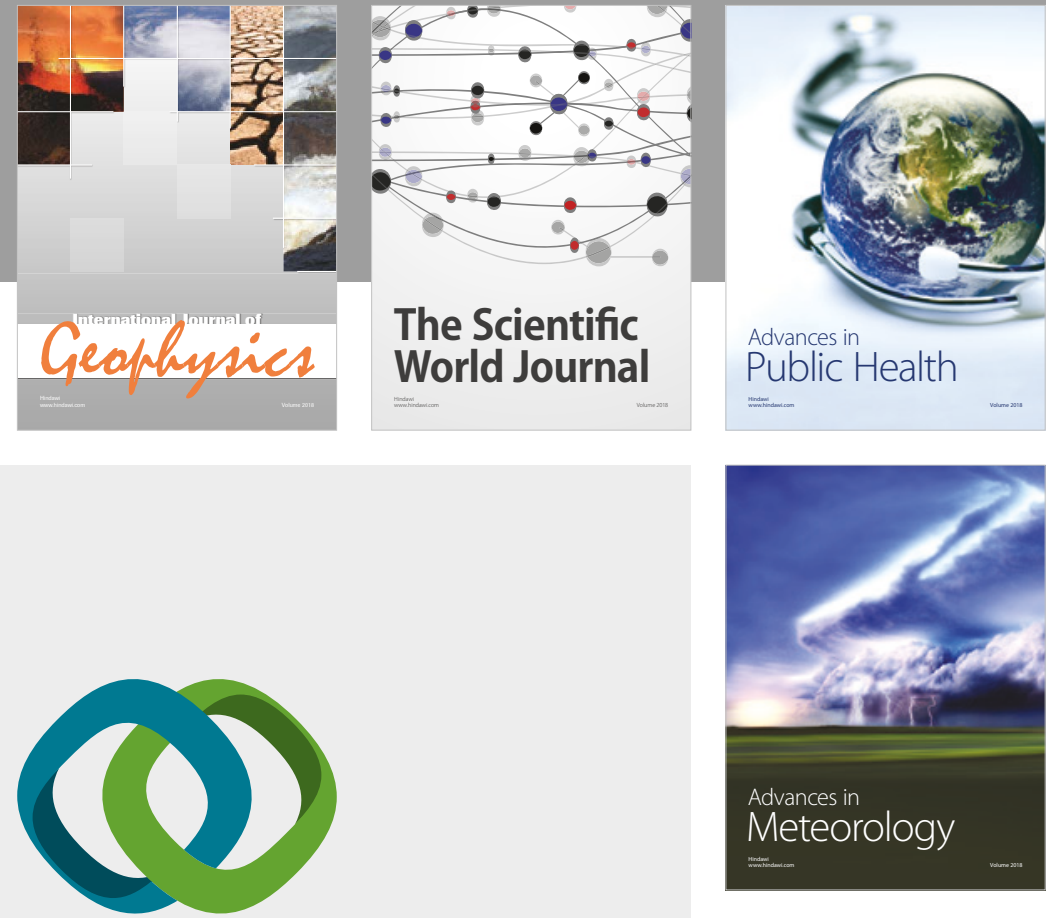

Advan

Public Health

\section{Hindawi}

Submit your manuscripts at

www.hindawi.com
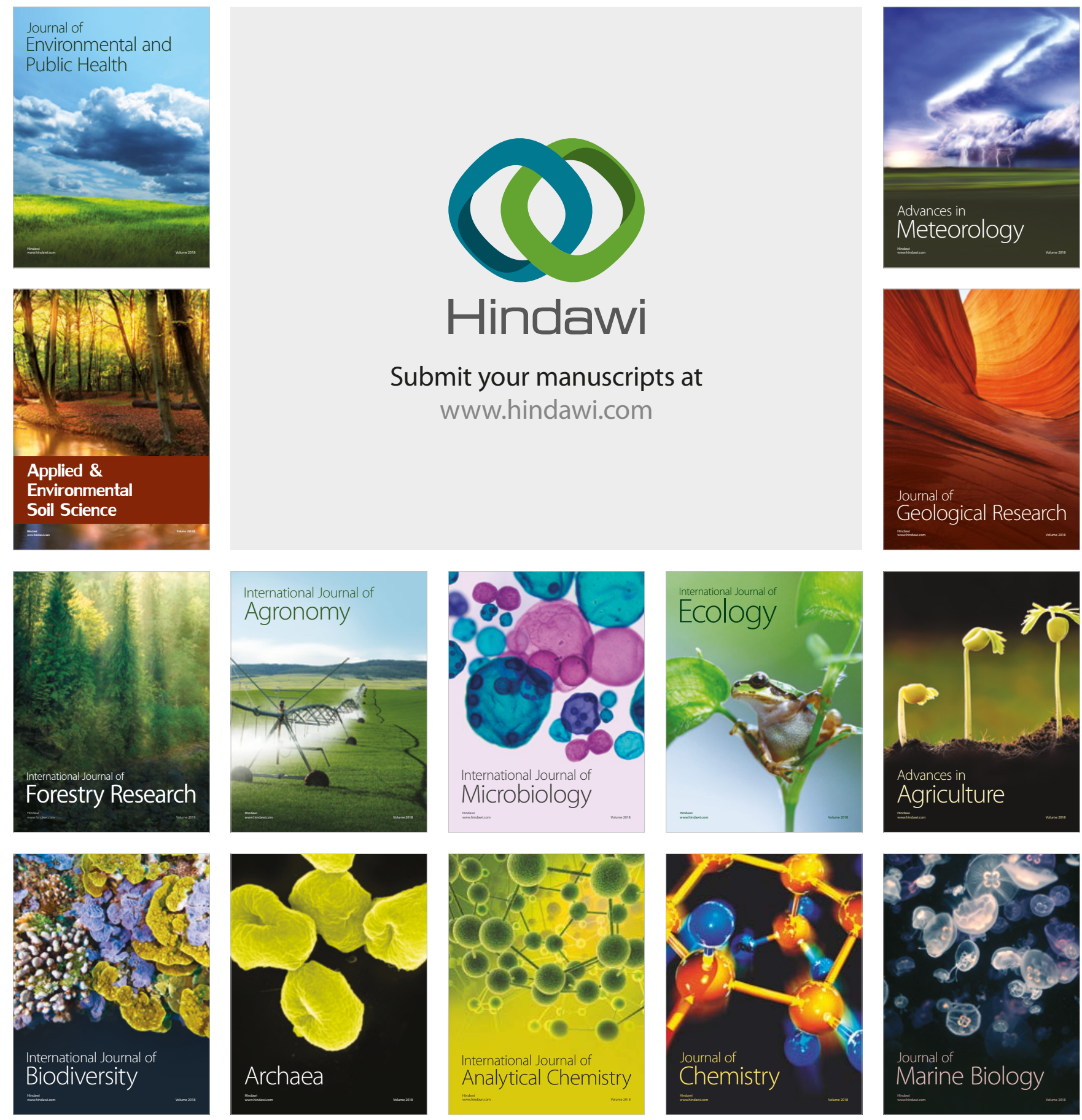